\title{
DIARREA VIRAL BOVINA: ESTUDIOS VIROLOGICOS DE UN TERNERO CON MALFORMACIONES
}

\author{
Gollan, A. E. ${ }^{1 ;}$ Rodriguez, R. ${ }^{2} ;$ Nogues, M. E. ${ }^{3}$ \& $\mathbf{O}$ cchi, H. ${ }^{1}$
}

\begin{abstract}
RESUMEN
El Virus de la Diarrea Viral Bovina es agente causal de cuadros clínicos desde inaparentes hasta graves patologías que incluyen abortos, malformaciones y nacimientos prematuros. En ellos se encuentran involucradas las Cepas citopatogénicas (CP) y las NO citopatogénicas(NCP). Se describen los estudios virológicos realizados a un ternero nacido con malformaciones (síndrome de idiocia, desarrollo anormal, hipoplasia tímica).

Se procesaron muestras del buffy coat por aislamiento, el suero por el test MPVIT y seroneutralización. Los resultados obtenidos indican el aislamiento del virus tanto de glóbulos blancos como de suero, a la vez que la serología para anticuerpos resultó negativa.

El aislamiento de una cepa CP de un animal con malformaciones, induce a pensar que la cepa NCP infectante in útero .podría haber mutado por efecto de recombinaciones celulares. Tales eventos son objeto de próximos estudios.

Palabras clave: diarrea viral bovina, malformación congénita, persistentemente infectado.
\end{abstract}

\section{SUMMARY}

\section{Bovine Viral Diarrhoea: Virological studies in a calf with malformations.}

The bovine viral diarrhoea is the responsible agent of clinical descriptions from non-apparent to serious pathologies including abortion, malformations and premature births. They are related to the cytophatogenic (CP) and noncytophatogenic (NCP) strains. Virologic studies performed on a calf born with malformations (idiocy, abnormal development, timic hypoplasia) are described.

The buffy coat samples were processed by isolation and the sera by the MPVIT test and seroneutralization. The results obtained show the virus isolation from both:white blood cells and the serum, and that the serology for antibodies was negative.

The isolation of a CP strain from an animal with malformations makes us think that a mutation in the original NCP uterine strain could have been caused by cellular recombinations. Such studies are to be developed in the future.

Key words: Bovine viral diarrohea, congenital malformation, persistently infected.

1.- Cátedra de Virología e Inmunología. Facultad de Ciencias Veterinarias, UNL. Kreder 2805.

3080, Esperanza, provincia de Santa Fe

2.- Cátedra de Clínica de grandes animales. Facultad de Ciencias Veterinarias, UNL.

3.- Pasante: estudiante de Medicina Veterinaria. Facultad de Ciencias Veterinarias, UNL.

Manuscrito recibido el 21 de agosto de 2002 y aceptado para su publicación el 2 de abril de 2003. 